\title{
Preservice English Language Teacher Education in the Anthropocene
}

\author{
Ahmet Erdost Yastibaş \\ Gazi University, Ankara, Turkey, e-mail: ahmeterdost@gmail.com
}

\begin{tabular}{|c|c|}
\hline ARTICLE INFO & ABSTRACT \\
\hline $\begin{array}{l}\text { Keywords: } \\
\text { English language teacher } \\
\text { education program, the } \\
\text { Anthropocene, program } \\
\text { evaluation, } \\
\text { environmental education }\end{array}$ & $\begin{array}{l}\text { The new geological epoch, the Anthropocene reveals the negative impacts of } \\
\text { human activities on the environment, which makes environmental education } \\
\text { significant to deal with the negative effects of people on the environment and } \\
\text { sustain the environment for the future of the world. As a branch of education, } \\
\text { English language teaching (ELT) can contribute to environmental education } \\
\text { in schools. For an effective environmental education in ELT, English language } \\
\text { teachers should have enough knowledge on environmental issues and } \\
\text { environmental awareness. One way for them to achieve this is preservice } \\
\text { English language teacher education. The literature review indicated that any } \\
\text { English language teacher education program (ELTEP) was not evaluated with } \\
\text { an anthropocentric perspective. Therefore, the present study aimed to } \\
\text { evaluate the new ELTEP of Turkey with an anthropocentric perspective. It was } \\
\text { designed as a qualitative study. The data was collected from the new ELTEP } \\
\text { of Turkey and was content analyzed. The findings of the study have shown } \\
\text { that environmental education is integrated with the new ELTEP through } \\
\text { community services and sustainable development and education courses. The } \\
\text { findings of the study were discussed and suggestions for further studies were } \\
\text { made. }\end{array}$ \\
\hline
\end{tabular}

How to cite:

Yastibaş, Ahmet Erdost. (2021). Preservice English Language Teacher Education in the Anthropocene. Indonesian Journal of English Language Teaching and Applied Linguistics, 5(2), 347-359

\section{Introduction}

The Anthropocene is the new geologic epoch that follows the Holocene and is a significant epoch for people to pay special attention to for the future and sustainability of the environment (Crutzen, 2006) owing to the negative impacts of human activities on the environment (Crutzen, 2006; Lewis \& Maslin, 2015; Steffen, Grinevald, Crutzen, \& McNeill, 2013; Zalasiewicz, Williams, Steffen, \& Crutzen, 2010; Zalasiewicz, Williams, Haywood, \& Ellis, 2011). Overpopulation (Crutzen, 2006; Steffen et al., 2013; Zalasiewicz et al., 2010), deforestation (Crutzen, 2006; Lewis \& Maslin, 2015; Steffen et al., 2013; Zalasiewicz et al., 2011), overuse of water resources (Crutzen, 2006; Steffen et al., 2013), and global warming (Crutzen, 2006; Lewis \& Maslin, 2015; Steffen et al., 2013; Zalasiewicz et al., 2010) are among human activities which have resulted in environmental pollution and ecological extinction (Crutzen, 2006). Human activities with such effects on the environment have dominated 
other natural forces in shaping the world (Crutzen, 2006; Lewis \& Maslin, 2015; Steffen et al., 2013; Zalasiewicz et al., 2011).

Owing to the destructive impacts of human activities on the environment, the Anthropocene emphasizes the significance of sustaining the environment for the future of the world. Thus, the Anthropocene makes environmental education necessary for the sustainability of the environment because the focus of environmental education is on environmental issues, and environmental education aims at promoting environmental awareness and moral readiness among people including teachers to encourage them to act pro-environmentally on an individual level (Abramovich \& Loria, 2015). Environmental education can give information about any issue such as policy related to sustainability, environmental dilemmas, environmental problems, and solutions to prevent these problems (Abramovich \& Loria, 2015). Thus, receiving this education, teachers, especially preservice teachers can become environmentally educated people and environmental educators (Álvarez-García, SuredaNegre, \& Comas-Forgas, 2015), become environmentally literate (Dada, Eames, \& Calder, 2017), and address environmental problems and act in favor of the environment (Abramovich \& Loria, 2015). They can also have the adequate preparation (Yavetz, Goldman, \& Pe'er, 2009), the knowledge on environmental issues (Borhan \& Ismail, 2011; Candan \& Erten, 2015; Çakır, İraz, \& Doğan, 2010; Esa, 2010), and environmental awareness (Candan \& Erten, 2015). Therefore, they can be confident and competent enough (Dada et al., 2017) to design environmental education (Yavetz et al., 2009), to introduce it (Álvarez-García et al., 2015), to deliver it (Dada et al., 2017) in their schools, and to integrate it into their teaching (Esa, 2010). Consequently, environmental education in teacher training (i.e. preservice and continuing professional development) is essential for the effective integration of environmental education (Álvarez-García et al., 2015). Also, the effective integration of environmental education points out the significant role of teachers in environmentally educating future citizens who are environmentally literate to participate in the decision-making process related to the environment (Çakır et al., 2010), who develop and adopt positive proenvironmental behaviors, policies, and attitudes (Anderson, Jagers, Lindskog, \& Martinsson, 2013; Álvarez-García et al., 2015), and who can lead the work aiming at protecting the environment (Esa, 2010).

The role of teachers in educating future citizens to protect and sustain the environment makes their preservice and continuing professional development training in environmental education important. Despite a few studies which have found out that preservice teachers have a high or moderate level of knowledge on environmental issues to introduce, deliver and integrate environmental education in their teaching (Çokçalışkan \& Çelik, 2017; Esa, 2010; Goulgouti, Plakitsi, \& Stylos, 2019), many studies have revealed that preservice teachers do not have enough knowledge on environmental issues to teach environmental education in their schools (Álvarez-García et al., 2015; Boon, 2010; Borhan \& Ismail, 2011; Campigotto \& Barrett, 2017; Çakır et al., 2010; Demir \& Avgın, 2016; Doğan, 2018; Gürsoy \& Sağlam, 2011; Tuncer Teksoz, Boone, Yilmaz Tuzun, \& Oztekin, 2014; Yavetz et al., 2009). In addition, according to the studies that have focused on inservice teachers, inservice teachers may not have the desired knowledge on environmental issues to teach it in their schools and/or may need further training in environmental education (Abramovich \& Loria, 2015; Borg, Gericke, Höglund, \& Bergman, 2014; Campbell, Medina-Jerez, Erdogan, \& Zhang, 2010; Garcia \& Cobar-Garcia, 2018; Okur-Berberoglu, Ozdilek, \& Yalcin-Ozdilek, 2014). According to several 
studies, the main reason for the lack of enough knowledge on environmental issues to teach them in schools is the lack of environmental education or inadequate environmental education in preservice teacher training (Álvarez-García et al., 2015; Boon, 2010; Borhan \& Ismail, 2011; Campigotto \& Barrett, 2017; Demir \& Avgın, 2016; Doğan, 2018). Yet, several studies have shown that when preservice and inservice teachers receive environmental education, they can improve their knowledge on environmental issues, have environmental awareness, and become environmentally literate (Álvarez-García et al., 2015; Anderson et al., 2013; Bertiz, Doğan, \& Erten, 2017; Candan \& Erten, 2015; Cebrián \& Junyent, 2015; Dada et al., 2017; Fettahlığlu, 2018; Genc, 2015; Hamalosmanoğlu, Kızılay, \& Kırmızıgül, 2020; OkurBerberoglu et al., 2014; Putri, 2018). Animated films (Hamalosmanoğlu et al., 2020), digital storytelling (Putri, 2018), panel (Anderson et al., 2013), drama (Bertiz et al., 2017), EcoFriendly Person Activity Package (Candan \& Erten, 2015), and project-based learning (Genc, 2015) were used in preservice environmental education, while education for sustainability course (Abramovich \& Loria, 2015) and outdoor education (Okur-Berberoglu et al., 2014) were used in environmental education with inservice teachers as continuing professional development.

As a discipline of education, English language teaching can also be used to teach environmental education to English language (EL) learners by improving their critical thinking skills (Erdem Mete, 2018; Nkwetisama, 2011). EL teachers can play an important role in educating EL learners environmentally (Nkwetisama, 2011). In this aspect, how EL teachers can educate their learners environmentally while teaching English to them may need further explanation. An EL teacher can educate his/her EL learners environmentally while teaching English in several ways. For example, he/she can ask his/her learners to write a cause-effect essay on an environmental issue such as "what are the causes and effects of global warming?" as an in-class activity or assignment after teaching how to write a cause-effect essay. To do this in-class activity or assignment, his/her EL learners may do some research about the causes and effects of global warming. While doing research, they may read some articles about global warming or watch videos about it. They may integrate what they learn through their research into their writing. Thus, this assignment can help them to practice what they learn about cause-effect essays and to learn about the causes and effects of global warming. This activity may raise their environmental awareness and think about the effects of their activities on the world. Another example can be that an EL teacher can teach a grammar topic such as type 2 conditionals by preparing activities or contextualizing the grammar lesson based on an environmental issue. To ask his/her EL students to write type 2 conditionals, he/she can prepare sentences such as "A lot of trees are cut to have more farming lands. Therefore, wild animals become endangered animals" and "People pollute the seas and oceans with plastic a lot, so many sea animals die every year." While writing type 2 conditionals, EL students can practice the target grammar structure and raise their environmental awareness. In both activities, the goals and objectives of the lessons can not be directly related to environmental education, but EL teachers can add a goal or objective related to environmental education as an extracurricular goal or objective.

For this, English language teacher education (ELTE) can help EL teachers to have environmental awareness (Nkwetisama, 2011) and enough knowledge on environmental issues to teach environmental education (Gürsoy \& Sağlam, 2011), yet it may not enable teachers to have enough and necessary knowledge for this (Gürsoy \& Sağlam, 2011) if it does 
not include environmental education in its curriculum or program because when ELTE includes environmental education, it can improve preservice EL teachers' awareness of environmental education (Putri, 2018). Therefore, ELTE should include environmental education in its curriculum so that preservice English language teachers can become environmentally educated people and environmental educators who have enough knowledge on environmental issues, incorporate environmental education in their teaching, and raise future citizens as environmentally educated people in the Anthropocene. To understand whether a preservice English language teacher education program (ELTEP) provides environmental education to preservice EL teachers, it can be evaluated with an anthropocentric perspective. Yet, the review of the studies on the evaluation of preservice ELTEPs has shown that several studies evaluated preservice ELTEPs according to EL teacher trainers (Yavuz \& Zehir Topkaya, 2013), student EL teachers (Dubetz \& Collett, 2020; Karim, Shaded, Mohamed, Rahman, \& Ismail, 2019; Kourieos \& Diakou, 2019; Uzun, 2016; Varol, 2018), or both (Coskun \& Daloglu, 2010; Kartal \& Başol, 2019; Rodríguez, 2016; Sulistiyo, Wiryotinoyo, \& Wulan, 2019; Zorba, 2015) in terms of their strengths and weaknesses (Coskun \& Daloglu, 2010; Sulistiyo et al., 2019; Yavuz \& Zehir Topkaya, 2013; Zorba, 2015) as well as their effectiveness in preparing preservice teachers to teach English (Dubetz \& Collett, 2020; Karim et al., 2019; Kartal \& Başol, 2019; Kourieos \& Diakou, 2019; Uzun, 2016; Varol, 2018). In addition, preservice ELTEPs of different countries were compared (Karakaş \& Yavuz, 2018), different preservice ELTEPs of Turkey were compared (Karakas, 2012; Öztürk \& Aydın, 2019; Solak, 2018), and the theoretical foundations (Ryan, Gladyo, Hobbs, Stargel, \& Williams, 2015) and effective pedagogical practices (Rodríguez, 2016) in a preservice ELTEP were expressed in other studies on the evaluation of preservice ELTEPs. As the literature review indicates, a preservice ELTEP has not been evaluated with an anthropocentric perspective in the literature. Therefore, the present study aimed to evaluate an ELTEP (which is (the new preservice ELTEP of Turkey prepared and introduced by the Higher Education Council of Turkey in 2018) with an anthropocentric perspective. Accordingly, the following question was tried to be answered: "Does the new English language teacher education program of Turkey allocate any course to environmental education?"

a. If so, what is/are the course/courses?

b. What is the content of the course/courses?

\section{Research Methodology}

\subsection{Research Design}

Qualitative research can allow for exploring an issue which according to Creswell and Poth (2018) can be human or social by providing a detailed and complex understanding of the issue (Creswell, 2007). Therefore, the present study employed qualitative research to evaluate the new ELTEP of Turkey in terms of the Anthropocene as an issue related to people through a detailed and complex understanding of this issue.

\subsection{Data Collection Tool}

The data was collected from Ingilizce Öğretmenliği Lisans Programı (English Language Teacher Education Program) prepared and published by the Higher Education Council of Turkey in 2018. 


\subsection{Data Analysis Procedure and Trustworthiness}

The data was content analyzed according to the framework suggested by Erlingsson and Brysiewicz (2017). As the first and second stages, the new ELTEP was read many times by the researcher to familiarize with the data and was divided into meaningful units. Then, codes were formulated from the document in the third stage. To make the present study trustworthy, the thick descriptions of the data were used.

\section{Findings}

Two themes emerged from the content analysis of the new ELTEP: social responsibility and sustainability. The findings were presented according to these themes in order.

\subsection{Social Responsibility}

Regarding the environment and environmental issues indicated by the Anthropocene, the community services course can be considered as a part of environmental education in the new ELTEP of Turkey because human activities in the environment can affect a society negatively by creating problems such as environmental pollution, global warming, and climate change which the community services course can also focus on as social problems. When preservice EL teachers receive community services course, they learn and study the followings:

1. understanding the concepts of community, community service, and social responsibility,

2. identifying contemporary social problems,

3. preparing projects to overcome social problems identified,

4. participating in social responsibility projects voluntarily,

5. participating in scientific events on social responsibility as the audience, presenters, or organizers, and

6. assessing and evaluating the results of social responsibility projects.

Studying and practicing these in community services course requires being active in social responsibility because of identifying, finding solutions to, participating in social responsibility projects related to, and evaluating the results of the projects related to social problems including the ones resulting from human activities in nature.

\subsection{Sustainability}

The sustainable development and education course can be considered as a part of environmental education in the new ELTEP of Turkey because it focuses on the relationship between people and the environment in terms of sustaining the environment for the future. In the sustainable development and education course, preservice EL teachers are trained on

1. education and sustainability,

2. the future of humanity and sustainability,

3. sustainable environment,

4. ecology,

5. global environmental problems and sustainability,

6. sustainable society in harmony with the environment,

7. population, economy, and sustainability,

8. technological developments and sustainability,

9. social responsibility projects, 
10. consumption habits and environment, and

11. the reconsideration of human and nature relation in terms of sustainability.

Studying sustainability in different aspects such as education, environment, ecology, population, economy, and environmental problems can provide knowledge on the relationship between people and the environment in terms of sustainability. It can also provide an understanding of how human activities can affect the future of the environment and people.

\section{Discussion}

The findings of the present study have indicated that the new ELTEP of Turkey includes environmental education through the community services and sustainable development and education courses, unlike the teacher education programs in which several studies revealed that preservice teachers receive little or no training on environmental education (ÁlvarezGarcía et al., 2015; Boon, 2010; Borhan \& Ismail, 2011; Campigotto \& Barrett, 2017; Demir \& Avgın, 2016; Doğan, 2018). According to the findings of the study, the new ELTEP of Turkey can help preservice EL teachers to learn more about environmental issues in the sustainable development and education course because its content presents and studies sustainability in terms of environment, ecology, environmental issues, the future of humanity, population, technological developments, the relationship between people and the environment, and consumption habits as Abramovich and Loria (2015) stated about the content of environmental education. As the sustainable development and education course in the new ELTEP deals with such subjects as environmental issues, sustainability, the reconsideration of the relationship between people and the environment, and the future of humanity and the environment, it can enable preservice EL teachers to notice how human activities have affected the nature negatively, which is the fundamental effect of the Anthropocene (Crutzen, 2006; Lewis \& Maslin, 2015; Steffen et al., 2013; Zalasiewicz et al., 2010; Zalasiewicz et al., 2011). Therefore, the content of sustainable development and education course can make preservice EL teachers environmentally literate and can improve their knowledge on the environment and environmental awareness similar to the preservice teachers who improved their knowledge on the environment and environmental awareness and became environmentally literate after having received environmental education in their teacher training program (Álvarez-García et al., 2015; Anderson et al., 2013; Bertiz et al., 2017; Candan \& Erten, 2015; Cebrián \& Junyent, 2015; Dada et al., 2017; Fettahlığlu, 2018; Genc, 2015; Hamalosmanoğlu et al., 2020; Okur-Berberoglu et al., 2014; Putri, 2018).

In addition to the sustainable development and education course, the present study has shown that the main focus of the community services course is on social responsibility. The content of the community services course includes social problems by identifying, finding solutions to, participating in the projects related to, and evaluating the results of the social responsibility projects related to social problems. Considering environmental issues as social problems, the community services course, together with the sustainable development and education course, can help preservice EL teachers to become environmentally educated people who can address environmental problems and act pro-environmentally on an individual level as Abramovich and Loria (2015) stated. This is because the community services course encourages them to take active parts in dealing with social problems including the ones resulting from environmental issues by requiring them to identify such 
problems, find solutions to them, participate voluntarily in social responsibility projects, and evaluate the results of social responsibility projects. This process in this course can improve preservice EL teachers' critical thinking skills, which is also important for environmental education (Erdem Mete, 2018; Nkwetisama, 2011).

The findings of the study have also demonstrated that the sustainable development and education course is theoretical, while the community services course is practical due to the contents of these courses. Receiving one theoretical and one practical course related to environmental education, preservice EL teachers can also become environmental educators who can become environmentally literate (Dada et al., 2017), have enough preparation (Yavetz et al., 2009), the knowledge on environmental issues (Borhan \& Ismail, 2011; Candan \& Erten, 2015; Çakır et al., 2010; Esa, 2010), and environmental awareness (Candan \& Erten, 2015). As a result, they can become confident and competent sufficiently (Dada et al., 2017) for designing environmental education (Yavetz et al., 2009), introducing it (Álvarez-García et al., 2015), delivering it (Dada et al., 2017) in their schools, and integrating it in their instruction (Esa, 2010).

An environmentally educated EL teacher can prepare a lesson plan as follow to teach both environmental education and English to his/her students:
A. Topic: Type 2 Conditional
B. Level: A2 (elementary)
C. Curricular objectives:

1. Raise the students' awareness of the fact that type 2 conditional is used to talk about hypothetical events at present.

2. Practice type 2 conditionals.

\section{Extra curricular objectives:}

1. Raise the students' awareness of how human activities may cause environmental issues.

\section{Lesson Stages:}

\section{- Warm-up}

The teacher shows his/her students a video about the effects of human activities on the environment and asks them to talk about the video in pairs or groups.

\section{- Presentation}

The teacher distributes the text below to the students and wants them to read the paragraph and answer the questions related to it.

\section{Text}

"Human activities around the world affect the world negatively. One of these activities is cutting down trees to have more lands for farming and building. Due to this, the rate of deforestation increases every year. As a result, many animals lose their habitats and become endangered animals. In addition to deforestation, people overuse water resources for farming and industrial activities. Therefore, the amount of clean drinkable water reduces every year, and this situation is a big problem for people. Besides these issues, the energy 
sources of people depend on fossil fuels a lot. Yet, using fossil fuels increases the amount of green house gases in the atmosphere. This leads to climate change and global warming."

\section{Questions}

1. Why do many animals become endangered?

2. Why is overusing water resources a problem?

3. What causes climate change and global warming?

After the reading activity, the teacher presents the following sentences on the board and gives information about how type 2 conditionals are formed and why they are used.

\section{Read situation 1}

People cut down a lot of trees for farming and building, so many animals lose their habitats.

\section{Hypothetical situation 1}

If people did not cut down a lot of trees for farming and building, many animals would not use their habitats.

\section{Real situation 2}

People overuse water resources for farming and industrial activities. Therefore, the amount of clean drinkable water reduces a lot.

\section{Hypothetical situation 2}

If people did not overuse water resources for farming and industrial activities, the amount of clean drinkable water would not reduce a lot.

\section{Real situation 3}

Using fossil fuels increases the amount of green house gases in the atmosphere. This leads to climate change and global warming.

\section{Hypothetical situation 3}

If fossil fuels were not used a lot, they would not lead to climate change and global warming. By using these examples, the teacher asks his/her students to complete the following rule chart:

1. Type 2 conditionals are used to talk about hypothetical/real situations at present.

2. Simple past tense/Simple present tense is used in if clause.

3. Would/will is used after if clause.

\section{- Practice}

The teacher asks his/her students to complete the sentences by using type 2 conditionals.

\section{Sentence completion exercise}

1. If there were a lot of trees around the world, ...

2. If people did not pollute the environment, ...

3. If there were no plastic in the oceans, ...

4. If people did not overhunt some animals, ...

5. If Anatolian lions were not extinct, ... 


\section{- Production}

The teacher asks his/her students to write a short paragraph about the following question:

"What would the world look like if global warming stopped?"

After the students write a short paragraph, the teacher first asks them to give feedback to each other's paragraphs and second presents some of the paragraphs on the board to give feedback.

\section{- Wrap-up}

The teacher distributes the self-check list to his/her students and asks them to complete the checklist.

\begin{tabular}{|l|l|l|}
\hline Items & Yes & No \\
\hline 1. I can use type 2 conditionals to talk about hypothetical situations at present. & & \\
\hline 2. I can make sentences by using type 2 conditionals. & & \\
\hline 3. I can understand how human activities may affect the world negatively. & & \\
\hline
\end{tabular}

\section{Conclusion}

The present study has evaluated the new ELTEP of Turkey with an anthropocentric perspective. According to the study, the new ELTEP of Turkey includes environmental education through two courses: the community services and sustainable development and education courses. The study has also demonstrated that the former course has a practical nature, while the latter has a theoretical nature because of the contents of these courses.

\section{Implications of the Study}

The Anthropocene shows that human activities have been affecting the environment and its sustainability very negatively. This situation calls for an interdisciplinary educational approach to educate students about this issue and raise them as individuals who care the environment and contribute to its sustainability. Accordingly, the interdisciplinary of this study shows that training preservice English language teachers about the environment through different courses such as the ones mentioned in this study can raise their awareness of the negative effects of human activities on the environment. Therefore, when they start to work, they can help their students to learn about this issue and grow as environmentally friendly individuals while their students learn English. These teachers can prepare English language teaching materials that focus on the environment and serve as tools to teach both English and environmental issues to their students. They can assess and evaluate their English language course books with an environmental perspective. If they find weaknesses in terms of the environment, they can improve their course books through several ways such as preparing their materials or adapting the available materials in the course to environmental education, so they can teach both English and environmental education to their students. 


\section{Limitations of the Study and Suggestions for Further Research}

This study has two limitations: (a) being designed as a qualitative study in which the data was collected from only one source (i.e. the new ELTEP of Turkey) and (b) being conducted in the Turkish teacher education context. Therefore, future studies can evaluate other ELTEPs in different teacher education contexts with an anthropocentric perspective by following the methodology of the present study. These studies can also include preservice EL teachers and EL teacher trainers in their anthropocentric evaluation of ELTEPs.

\section{References}

Abramovich, A., \& Loria, Y. (2015). The long-term impact of an education for sustainability course on Israeli science and technology teachers' pro-environment awareness, commitment and behaviour. Australian Journal of Environmental Education, 31(2), 262279. DOI: 10.1017/aee.2015.31

Álvarez-García, O., Sureda-Negre, J., \& Comas-Forgas, R. (2015). Environmental education in pre-service teacher training: A literature review of existing evidence. Journal of Teacher Education for Sustainability, 17(1), 72-85. DOI: 10.1515/jtes-2015-0006

Andersson, K., Jagers, S. C., Lindskog, A., \& Martinsson, J. (2013). Learning for the future? Effects of education for sustainable development (ESD) on teacher education students. Sustainability, 5, 5135-5152. DOI:10.3390/su5125135

Bertiz, H., Doğan, A., \& Erten, S. (2017). The role of drama in raising environmental awareness in preservice science teachers. International Online Journal of Educational Sciences, 9(4), 1052-1074. DOI: 10.15345/iojes.2017.04.012

Boon, H. J. (2010). Climate change? Who knows? A comparison of secondary students and pre-service teachers. Australian Journal of Teacher Education, 35(1), 104-120.

Borg, C., Gericke, N., Höglund, H. O., \& Bergman, E. (2014). Subject- and experience-bound differences in teachers' conceptual understanding of sustainable development. Environmental Education Research, 20(4), 526-551. DOI: 10.1080/13504622.2013.833584

Borhan, M. T., \& Ismail, Z. (2011). Pre-service teachers' perception toward environmental knowledge, attitudes and behaviours. Malaysian Journal of Learning and Instruction, 8, 117-137.

Çakır, M., İrez, S., \& Kıvılcan Doğan, Ö. (2010). Understandings of current environmental issues: Turkish case study in six teacher education colleges. Educational Studies, 36(1), 21-33. DOI: 10.1080/03055690903148522

Campbell, T., Medina-Jerez, W., Erdogan, I., \& Zhang, D. (2010). Exploring science teachers' attitudes and knowledge about environmental education in three international teaching communities. International Journal of Environmental \& Science Education, 5(1), 3-29.

Campigotto, R., \& Barrett, S. E. (2017). Creating space for teacher activism in environmental education: Pre-service teachers' experiences. Canadian Journal of Environmental Education, 22, 42-57.

Candan, S., \& Erten, S. (2015). Pre-service teacher opinions about eco-friendly person activity package developed to raise environmental awareness. International Electronic Journal of Environmental Education, 5(2), 62-85.

Cebrián, G., \& Junyent, M. (2015). Competencies in education for sustainable development: Exploring the student teachers' views. Sustainability, 7 , 2768-2786. DOI:10.3390/su7032768 
Çokçalışkan, H., \& Çelik, Ö. (2017). Investigation of pre-service classroom teachers' environmental awareness and attitudes. International Electronic Journal of Environmental Education, 7(2), 73-83.

Coskun, A., \& Daloglu, A. (2010). Evaluating an English language teacher education program through Peacock's model. Australian Journal of Teacher Education, 35(6), 24-42.

Creswell, J. W. (2007). Qualitative inquiry \& research design: Choosing among five approaches $\left(2^{\text {nd }}\right.$ ed.). Sage Publications.

Creswell, J. W., \& Poth, C. N. (2018). Qualitative inquiry \& research design: Choosing among five approaches ( $4^{\text {th }}$ ed.). Sage Publications Inc.

Crutzen, P. J. (2006b). The Anthropocene: The current human-dominated geological era. Retrieved from www.pas.va/content/dam/accademia/pdf/acta18/acta18-crutzen.pdf

Dada, D. O., Easmes, C., \& Calder, N. (2018). Impact of environmental education on preservice beginning teachers' environmental literacy. Australian Journal of Environmental Education, 33(3), 201-222. DOI: 10.1017/aee.2017.27

Demir, P., \& Avgın, S. S. (2016). Global warming and measures to be taken: Pre-service science teachers' views. Journal of Education and Practice, $7(27), 128-135$.

Doğan, Y. (2018). Investigation of preservice teachers' knowledge related to basic concepts of environmental phenomenon. Journal of History Culture and Art Research, 7(5), 47-66. DOI: $10.7596 /$ taksad.v7i5.1770

Dubetz, N., \& Collett, J. (2020). Studying program effectiveness in preparing teachers for English learners. Action in Teacher Education, 42(3), 190-211. DOI: 10.1080/01626620.2019.1650400

Erdem Mete, D. (2018). Incorporating environmental education in English language teaching through Bloom's revised taxonomy. SEFAD, 40, 33-44. DOI: 10.21497/sefad.514847

Erlingsson, C., \& Brysiewicz, P. (2017). A hands-on guide to doing content analysis. African Journal of Emergency Medicine, 7, 93-99.

Esa, N. (2010). Environmental knowledge, attitude and practices of student teachers. International Research in Geographical and Environmental Education, 19(1), 39-50. DOI: 10.1080/10382040903545534

Fettahlıoglu, P. (2018). The effects of argumentation implementation on environmental education self efficacy beliefs and perspectives according to environmental problems. Journal of Education and Training Studies, 6(4), 199-211. DOI: 10.11114/jets.v6i4.2925

Garcia, M. N. Z., \& Cobar-Garcia, M. R. V. (2018). The environmental literacy of elementary school teachers based in the city of Manila and Nueva Ecija province. Journal of Nature Studies, 17(2), 10-29.

Genc, M. (2015). The project-based learning approach in environmental education. International Journal in Geography and Environmental Education, 24(2), 105-117. DOI 10.1080/10382046.2014.993169

Goulgouti, A., Plakitsi, A., \& Stylos, G. (2019). Environmental literacy: Evaluating knowledge, affect, and behavior of pre-service teachers in Greece. Interdisciplinary Journal of Environmental and Science Education, 15(1), 1-9. DOI: 10.29333/ijese/6287

Gürsoy, E., \& Sağlam, G. T. (2011). ELT teacher trainees' attitudes towards environmental education and their tendency to use it in the language classroom. Journal of International Education Research, 7(4), 47-52.

Hamalosmanoğlu, M., Kızılay, E., \& Saylan Kırmızıgül, A. (2020). The effects of using animated films in the environmental education course on prospective teachers' behavior 
towards environmental problems and their attitude towards solid waste and recycling. International Online Journal of Education and Teaching, 7(3), 1178-1187.

Karakas, A. (2012). Evaluation of the English language teacher education program in Turkey. ELT Weekly, 4(15), 1-16.

Karakaş, A., \& Yavuz, E. (2018). A comparative analysis of English language teacher education programs in Turkey and Malaysia. Cumhuriyet International Journal of Education, 7(3), 287-306. DOI: 10.30703/cije.446313

Karim, A., Shahed, F. H., Rahman, M. M., Mohamed, A. R., \& Ismail, S. A. M. M. (2019). Evaluation of the teacher education programs in EFL context: A testimony of student teachers' perspective. International Journal of Instruction, 12(1), 127-146. DOI: 10.29333/iji.2019.1219a

Kartal, G., \& Başol, H. Ç. (2019). Generic teacher competencies and the English teacher education program in Turkey. Novitas-ROYAL (Research on Youth and Language), 13(2), 133-154.

Kourieos, S., \& Diakou, M. (2019). Pre-service English language teacher education and the first years of teaching: Perspectives from Cyprus. The New Educator, 15(3), 208-225. DOI: 10.1080/1547688X.2019.1628558

Lewis, S. L., \& Maslin, M. A. (2015). Defining the Anthropocene. Nature, 519, 171-180.

Nkwetisama, C. M. (2011). EFL/ESL and environmental education: Towards an eco-applied linguistic awareness in Cameroon. World Journal of Education, 1(1), 110-118. DOI: 10.5430/wje.v1n1p110

Okur-Berberoglu, E., Ozdilek, H. G., \& Yalcin-Ozdilek, Ş. (2014). The short term effectiveness of an outdoor environmental education on environmental awareness and sensitivity of in-service teachers. International Electronic Journal of Environmental Education, 5(1), 120.

Öztürk, G., \& Aydın, B. (2019). English language teacher education in Turkey: Why do we fail and what policy reforms are needed? Anadolu Journal of Educational Sciences International, 9(1), 181-213. DOI: 10.18039/ajesi.520842

Putri, I. G. A. P. E. (2018). Critical environmental education in tertiary English language teaching (ELT): A collaborative digital storytelling project. Indonesian Journal of Applied Linguistics, 8(2), 336-344. DOI: 10.17509/ijal.v8i2.13280

Rodríguez, M. E. (2016). Effective pedagogical practices in online English language teacher education (Unpublished doctoral dissertation). The Graduate College, the University of Arizona, Arizona.

Ryan, P., Glodjo, T., Hobbs, B., Stargel, V., \& Williams, T. (2015). Navigating complexities: An integrative approach to English language teacher education. Issues in Interdisciplinary Studies, 33, 181-209.

Solak, E. (2018). An administrative overview of English language teacher education programs in Turkey. International Journal of Language Academy, 6(5), 70-76. DOI: 10.18033/ijla.3995

Steffen, W., Grinevald, J., Crutzen, P., \& McNeill, J. (2011). The Anthropocene: Conceptual and historical perspectives. Philosophical Transactions of the Royal Society A, 369, 842867.

Sulistiyo, U., Wiryotinoyo, M., \& Wulan, R. (2019). Examining an English as a Foreign Language Teacher Education Program (EFLTEP)'s curriculum: A case study in an Indonesian university. European Journal of Educational Research, 8(4), 1323-1333. DOI: 10.12973/eu-jer.8.4.1323 
The Higher Education Council of Turkey. (2018). Ingilizce Öğretmenliği Lisans Programı (English Language Teacher Education Program). Retrieved from https://www.yok.gov.tr/Documents/Kurumsal/egitim ogretim dairesi/Yeni-OgretmenYetistirme-Lisans-Programlari/Ingilizce Ogretmenligi Lisans Programi.pdf

Tuncer Teksoz, G., Boone, J. W., Yilmaz Tuzun, O., \& Oztekin, C. (2014). An evaluation of the environmental literacy of preservice teachers in Turkey through Rasch analysis. Environmental Educational Research, 20(2), 202-227. DOI: $10.1080 / 13504622.2013 .768604$

Uzun, L. (2016). Evaluation of the latest English language teacher training program in Turkey: Teacher trainees' perspective. Cogent Education, 3(1), 1-16. DOI: 10.1080/2331186X.2016.1147115

Varol, B. (2018). Evaluation of an English language teacher education program from student teachers' pespectives: A case from Turkey. International Journal of Field Education, 4(2), 83-96.

Yavetz, B., Goldman, D., \& Pe'er, S. (2009). Environmental literacy of pre-service teachers in Israel: A comparison between students at the onset and end of their studies. Environmental Educational Research, 15(4), 393-415. DOI: 10.1080/13504620902928422

Yavuz, A., \& Zehir Topkaya, E. (2013). Teacher educators' evaluation of the English language teaching program: A Turkish case. Novitas-ROYAL (Research on Youth and Language), $7(1), 64-83$.

Zalasiewicz, J., Williams, M., Haywood, A., \& Ellis, M. (2011). The Anthropocene: A new epoch of geological time? Philosophical Transactions of the Royal Society A, 369, 835-841.

Zalasiewicz, J., Williams, M., Steffen, W., \& Crutzen, P. (2011). The new world of the Anthropocene. Environmental Science \& Technology, 44, 2228-2231.

Zorba, Ş. (2015). Evaluating the undergraduate English language teacher education program at Eastern Mediterranean University (Unpublished master's thesis). Institute of Graduate Studies and Research, Eastern Mediterranean University, Gazimağusa, North Cyprus. 